\title{
France seeks to tighten its control over life sciences
}

Paris. An announcement last week by France's Ministry of Higher Education and Research that it intends to take direct control of a new national strategy for the life sciences suggests that the government may be on a collision course with the main research organizations over who should control the future direction of research.

Reinforcing this impression is the fact that, at a press conference held to announce the strategy, François Fillon, the minister for higher education and research, was flanked by civil servants - not by senior officials from the research organizations, a large number of whom sat among the audience.

Under the new strategy, the minister will set up 14 scientific committees. These will be responsible for carrying out the peer review and financing of projects in 14 'strategic' programmes divided into seven priority areas.

There will, for example, be three programmes in genetics, namely structural and functional analysis of genomes, human genetics, and genetics and environment. Similarly, 'physiopathological mechanisms' will include four areas: cardiovascular physiopathology and pharmacology; biopathology of prions; cellular imagery and mechanics, and neurobiopathology; and the development of functional imagery.

In addition, there will be two 'horizontal' programmes, one on bioinformatics and one on biotechnology. Total funding of FF250 million (US\$50 million) over two years will come from ministry funds.

According to Fillon, projects will be selected for funding if they are considered to have an "innovative dimension" that has been given inadequate attention by the national research organizations.

\section{Gravity scores one, microgravity zero}

Paris. Microgravity research crashed to Earth two weeks ago when bad weather forced a helicopter to jettison a Russian Photon 10 capsule containing a series of experiments in life sciences. The helicopter had been transporting the capsule from its landing site in Kazakhstan to the nearby airport at Erenbourg.

The capsule, which landed on 3 March after 15 days in orbit, was seriously damaged, and the accident also destroyed the French instrument IBIS (Instrument pour la Biologie dans l'Espace), which was flying the first of a series of planned biannual missions.

According to the French space agency CNES, 50 of the 64 cassettes containing biological material used in the IBIS experiments have been recovered. But it
An official from the Centre National de la Recherche Scientifique (CNRS) says that he welcomes the fact that the science ministry has been able to obtain extra funds for life sciences from the finance ministry, particularly in the austere financial climate.

Of the promised FF250 million, FF153 million is guaranteed, while the remainder will be subject to approval by parliament in the autumn. These figures are significant, given that total funding of CNRS life science laboratories (excluding salaries) this year is FF346.4 million.

But the same official is concerned that the ministry has decided to administer the new money directly rather than pass it on to the research organizations. One explanation, say observers, is that the money was obtained by groups at the ministry that favour strong government intervention. Claude Griscelli, an adviser to Fillon, is considered the architect of the new plan.

Indeed, giving responsibility for the management of the programmes to committees within the ministry seems to fly in the face of Fillon's much vaunted policy of defining a national strategy by negotiating objectives (and their budgets) with the research organizations themselves through a new system of five-year contracts. "Does this mean Fillon lacks faith in his ability to administer such contracts?" asks one observer.

Others are sceptical that the ministry, which has only a small staff, most of whose time is tied up with university issues, has sufficient resources to manage 14 national programmes. They point out that research organizations such as the medical research agency (INSERM) already have well-developed systems for evaluating programmes.

Declan Butler

will be several weeks before their condition is known.

The accident represents a "complete catastrophe", according to Lydie Gualandris-Parisot, a researcher at the CNRS laboratory of molecular and cellular mechanisms of embryogenesis in Toulouse, which had flown a series of experiments on the development of the nervous and muscular systems of the amphibian Pleurodeles aboard the fated mission.

The laboratory has recovered fewer than one-fifth of the experimental specimens, she says, and these are in poor condition; obtaining any meaningful results from the partial data will be "next to impossible". The only way to recover six years of work spent planning the experiments, she says, will be to re-fly the experiment.

D. B.
EU commissioner sets sights on closer ties with industry

Paris. Edith Cresson, the research commissioner of the European Union (EU), last week announced plans to create joint taskforces with the European Commission's industry directorate (DG III) in five areas: vaccines against viral infections, educational software and multimedia; and the "cars, trains and aircraft of tomorrow".

Cresson was speaking at a meeting of the EU research ministers, the first at which she has represented the Commission since her appointment late last year. According to an official, the setting up of the task forces confirms the growing role of the industry directorate in deciding research policy.

But observers say that Cresson made less progress on gaining support for her controversial proposal to use the ECU700 million (US\$925 million) held in reserve for the next framework programme to give the programme a greater industrial flavour.

The Council also agreed that better coordination is needed between the EU's research policies and those of the member states. But it described as "premature" proposals from the Commission to include in the framework programme joint programmes involving some - but not all member states (see Nature 371, 728; 1994).

Nor was it yet prepared to back programmes set up by several member states outside the framework programme - even though power to do so was given to the Commission under the Maastricht treaty. Coordination should be pursued instead, it said, through existing structures.

This refers to the programme committees and the Science and Technology Research Committee (CREST), a body made up of two members from each country and chaired by the Commission.

One Commission official points out that no role in promoting coordination was proposed at the meeting for the European Science and Technology Assembly (ESTA), an advisory body mainly made up of scientists which was created last year by Antonio Ruberti, Cresson's predecessor. One interpretation is that the assembly is now unlikely to be given a major say in policy decisions.

Attempts by the Council to transform CREST into a more powerful tool of its own interests met with mixed success (see Nature $370,166 ; 1994)$. The meeting agreed that CREST should be strengthened and given more political influence, enabling it to play a bigger role in defining longer-term EU research strategies.

But the Council was divided about whether the committee should be chaired in rotation by member states - as several would like - or be chaired by the Commission, as at present. 